\author{
Elena Vyushkina
}

Saratov State Law Academy

Russia

e-mail: vyushkina@gmail.com

ORCID: 0000-0002-0004-1262

\title{
LAW SCHOOL LEARNING OUTCOMES: LEGAL ENGLISH COURSE CONTRIBUTION
}

\begin{abstract}
Standards of professional legal education are developed by different organizations: in some countries these are governmental bodies, in others these are professional associations. Apart from a country these standards include Learning Outcomes which shape law schools' curricula. Both American and European standards mention, to different extent, written and oral communication in the legal context, but a number and contents of subjects directed at developing and mastering professional communicative competency differ a lot. There are disciplines totally devoted to the competency named (e.g. legal writing) as well as courses in which communicative skills are an integral constituent for their successful completion (e.g. basis of negotiations/mediation/client consultation).

The article goal is to find a place and role of a Legal English (LE) course in achieving learning outcomes connected with professional communicative competence. The methodology incorporated desk and field studies. The literature review is aimed at identifying current state of affairs in American law schools, as they provide first-class legal education recognized all over the world, and in Russian law schools, as the author works in this system and is interested in its development. A questionnaire was designed to explore Russian law school graduates' assessment of practicality of subjects they had studied for their professional activities.

The analysis of literature and Internet sources allowed to specify the ways of teaching written and oral communication in American law schools and to highlight the situation in Russian legal education. It shows that the Russian system is characterized by predominance of teaching theory of substantive and procedural rules of law and lack of curriculum disciplines aimed at cultivating skills and competencies.

A survey of Russian law schools' recent graduates indicates that most of communicative, in a broad sense, skills, which they use in their everyday work, were obtained within their LE classes. So, complementing a LE course with modules devoted to different aspects of legal writing and specific patterns of lawyer-client, lawyer-lawyer, lawyer-judge communication will definitely contribute to achieving learning outcomes which are put forward by legal education standards.
\end{abstract}

Keywords: Legal English, professional communication, lawyering skills, learning outcomes, CLIL. 


\section{Introduction}

Higher education is aimed at preparing a competent specialist and legal education is not an exception. Educational standards are set up by different organizations depending on a country: Ministries of Education, governmental agencies, and/or professional associations. Usually these standards include learning goals, tasks, and outcomes which shape law schools' curricula. Both American and European standards mention, to different extent, written and oral communication in the legal context, moreover, such communication is named among the ten fundamental lawyering skills (MacCrate, 1996: 645). Nevertheless, a number and contents of subjects directed at developing and mastering professional communicative competency differ a lot. Some disciplines are totally devoted to framing and developing the named competency, for instance, "Legal Writing", others are aimed at training such lawyering skills as client counseling and negotiation but communicative skills are an integral constituent for their successful completion.

In the U.S.A. legal education is controlled by American Bar Association (ABA) which accredits law schools, conducts a bar exam, and advises law school curricula. National Conference of Bar Examiners (NCBE) Task Force conducts a continuous work of developing requirements to learning outcomes in response to changing demands of a modern society. Although law schools' curricula have been changing in favor of skill-oriented courses in recent years, many "practicing lawyers continue to challenge the legal academy to provide more instruction in skills and practical training, and spend less time focusing on esoteric issues and scholarly debates" (Thompson, 2009). A large-scale survey-based study conducted by the NCBE (Case 2013) provided an impetus towards further developments and changes in requirements to legal education outcomes. Furthermore, in October 2017 a Testing Task Force was formed by NCBE's Board of Trustees to conduct a three-year study "to ensure that the bar examination continues to test what is necessary for competent entry-level legal practice in a changing profession" (Martin 2019: 1).

In Russia educational standards are worked out and approved by the Ministry of Science and Higher Education and named Federal State Educational Standards (FSES). Learning outcomes are described through competences which a graduate must attain (Zimnaya 2013). They are divided into general cultural competences (GCC), general professional competences (GPC), and professional competences (PC) and used in defining goals of courses. A particular discipline syllabus uses such terms as compe- 
tences formed and knowledge and skills attained as a result of the discipline studying. The purpose of this article is not to clarify the terminology used - competences, skills, attributes - but to find out what graduates should be able to do and use at their working place that is why these terms will be considered interchangeable in this work.

Legal education has a long history but modern world is changing very quickly and curriculum developers and designers should always keep in mind questions: What law school learning outcomes do employers want graduates to have? What knowledge and competences should be included in standards and requirements? What skills and attributes are crucial for a graduate to become a professional? How to combine academic knowledge with practical skills?

The author will try to answer these questions while analyzing policy documents of educational authorities and academic literature, by considering surveys results, through suggesting solutions and Legal English (LE) course syllabus elements.

This article goal is to find a place and role of a LE course in achieving learning outcomes connected with professional communicative competence, in particular, to elicit syllabus elements and assignments aimed at framing and mastering such lawyering skills as professional written and oral communication. The methodology incorporated desk and field studies. The literature review aimed at identifying current state of affairs in American law schools, as they provide first-class legal education recognized all over the world, and in Russian law schools, as the author works in this system and is interested in its development. A questionnaire was designed to explore Russian law school graduates' assessment of practicality for their professional activities of subjects they had studied.

\section{Teaching professional skills in US law schools}

Evaluation of educational program results can be carried out by different means; surveys of graduates and employers are one of them. The National Conference of Bar Examiners ordered a job analysis survey of Newly Licensed Lawyers (NLL) (the term "newly licensed lawyer" refers to a lawyer who has been in practice from 1 to 5 years (Martin 2019: 8)). NLLs were asked to evaluate the importance of knowledge and skills attained at their law school in relation to their activities at a working place. They used a 1-4 scale (4 standing for "extremely significant") to assess different rubrics in two lists: "Knowledge Domains" (86 rubrics) and "Skills 
and Abilities" (36 rubrics). The result turned out to be very interesting and challenging curriculum designers' mind. Rules of Civil Procedure with average significance 3.08 was in the first line of "Knowledge Domains". At the same time Written communication got average significance 3.77 in "Skills and Abilities" followed by 24 more rubrics having received scores higher than 3.08 (Case 2013). Thus, knowledge of substantive and procedural rules seems to be less important in a real-case scenario than skills and abilities.

Using the results of this survey Bratman (Bratman 2015) classified these twenty five skills and abilities into five categories, specifically: communication, analysis, research, project management, professionalism. The importance of these findings was considered at a Legal Writing conference and led to the conclusion to use them as a "starting point" in developing ABA's new standards requirements. In terms of author's research communication and analysis categories are of primary importance because most of the skills enumerated there are included into the FSES as competences defining learning outcomes. They are written and oral communication, listening, asking and answering questions in a concise and clear way, critical reading/comprehension and issue spotting, to name a few.

It should be mentioned that issues of reflecting lawyering skills importance in educational standards have been in the focus of American scholars and practitioners for rather long. Ways "to overcome the tendency in law schools to separate the teaching of legal theory from instruction in its practical application in society" (MacCrate 1996) started to being sought at the end of the last century although such courses as "legal analysis and reasoning," "legal research," and "legal writing," had been taught in American law schools for a long time. Client counseling and negotiation courses appeared in curricula together with introducing learning-by-doing methods in teaching core subjects (MacCrate 1996). Moreover, clinical education or semester-in-practice became an integral part of law school curricula and now $\mathrm{ABA}$ requires having "at least six credits in experiential courses as a condition of graduation" (Kruse 2015).

A diversity of American law schools' curricula within the ABA standards is great and while legal writing is a compulsory law school first year subject "client interviewing, case preparation, and trial advocacy" are taught in law schools around the country to different extent (Levinson 2010). Lawyers who turn to teaching after years of practice try to incorporate skills mastering into theoretical disciplines. Christensen (Christensen 2012) indicates that "combining skills and doctrine in every law 
school course" intensifies students' leaning and prepares them for real life. He found out that cooperative learning is one of the reasons for law school success and such activities as work in pairs or small groups and preparing short presentations can be easily included in any class (Christensen 2012). One more way of developing lawyering skills in general and professional communicative competence in particular, is law clinics. Clinic pedagogy has evolved from client counseling to creating mediation programs and clinics against the background of alternative dispute resolution development.

Summing up the above it should be kept in mind that the NCBE Testing Task Force is in the middle of its three-year study and the Practice Analysis Survey starting on August 1, 2019 (https://www.testingtaskforce.org/2019 pasurvey/) will give insights on the content and ways of teaching from viewpoints of both NNLs and experienced professionals and will definitely lead to further changes of American law school curriculum frameworks. As for now, students can choose from a rather wide range of skill-oriented courses such as legal writing, trial advocacy, negotiations as well as get practical experience in law clinics and mediation clinics. Nevertheless, there are also skills important for future practice, so-called soft skills (listening, oral communication, interpersonal skills, etc.), which can be shaped and developed within various disciplines

\section{Teaching professional skills in Russian law schools}

Nowadays a Russian system of higher education draws on competence approach and universities use FSESes developed by the Ministry of Science and Higher Education in shaping their curricula for different majors (Portal, n/d). A FSES for a particular major in terms of studied subjects usually contains compulsory and variable parts: universities can vary only academic load within the compulsory part and have more freedom while developing the variable part. A baccalaureate professional training program of higher education developed at Saratov State Law Academy (major - jurisprudence 40.03.01) (Saratov $\mathrm{n} / \mathrm{d}$ ) was used to analyze the situation with teaching skills in Russian law schools. This curriculum is worked out in conformity with the FSES and includes general remarks, requirements to learning outcomes in the form of competences formed within the program, overviews of disciplines' syllabi, etc. It is necessary to underline that Saratov State Law Academy is a typical example of a state Russian law school which follows the FSES in creating its curriculum. 


\section{Elena Vyushkina}

The analysis showed that only a few courses are directly aimed at shaping and developing lawyering skills. They are disciplines of a FSES variable part, for instance, 'Russian language and speech culture', 'Legal reasoning', 'Legal methods', each is worth 2 credit hours. The syllabi of the mentioned courses indicate PC-7 (having skills of drafting legal documents) as one of the learning outcomes but this particular competence is mentioned among results of studying of many law courses as well. GPC-5 (having an ability to reasonably and clearly perform oral and written communication) and GCC-5 (having ability to communicate orally and in writing in Russian and foreign languages to resolve tasks of interpersonal and cross-cultural interaction) are named as outcomes of studying the first two from above mentioned disciplines.

The syllabi of such compulsory courses of the FSES basic part as 'Foreign language' and 'Foreign language in the sphere of jurisprudence' indicate communicative competence in a foreign language (GPC-7) as one of the learning outcomes, others are GCC-5 and GPC-5 mentioned above. In fact, elements of business and legal correspondence which students learn within these courses contribute to developing a written communication skill much more than it is done during teaching other courses (the conclusion made out of empirical data received from years of teaching experience).

One more way to gain communicative skills is to work at a law clinic. Although almost all law schools in Russia have law clinics, practicing at a law clinic is not compulsory for students. Students regard working at a law clinic as an extra-curriculum activity rather than an academic discipline. Nevertheless, these students who do enroll in a law clinic highly appreciate the experience they get there.

There is one more skill-oriented course 'Conflict resolution studies' aimed at forming communicative competence and negotiating skills but it is an optional one and not many students take it.

Summing up the above one can conclude that in theory many disciplines have various professional competences indicated as learning outcomes but in practice there is a lack of skill-oriented courses. Thus, there is a task to find ways to implement modules and elements for developing and mastering lawyering skills, communication and analysis in particular, into teaching disciplines even if they seem to be totally doctrineoriented. Foreign language (FL) is a skill-oriented course and it can be easily amplified by elements, tasks, and assignments aimed at mastering lawyering skills, especially those which compose communication and analysis categories. 


\section{Law School Graduates Survey}

As it is mentioned above, learning outcomes can be assessed by a graduates' survey, as one of the ways of evaluation. Having taken the idea to assess the importance of different knowledge and skills for job activities (Case 2013) the goal was changed. The aim of the survey was not only to indentify the most important skills and knowledge at a working place but to find out sources they had been obtained from.

The offered questionnaire contained ten rubrics in each of two categories "Knowledge Domains" and "Skills". The former was composed of disciplines included in State Qualification Exams and courses which are worth more credit hours: Civil Law, Criminal Law, Civil Procedure, Criminal Procedure, Theory of State and Law, Family Law, Arbitrazh (it is necessary to clarify that Russian tern "arbitrazh" has nothing in common with arbitration (a way of alternative dispute resolution); it is used to name Commercial law), etc. The latter included skills connected with communication such as written communication, oral communication, client interviewing, drafting contract, preparing complaints, negotiations, communication with the other party, etc. There was an open question line "other" in each category.

The research sample comprised Saratov State Law Academy graduates of 2015-2018 who had not passed a Bar exam yet. (A note: in Russia a law school graduate who has not passed a Bar exam can be involved in any kind of activities but representing clients in criminal courts). The questionnaire was distributed through e-mail and social net VK to author's former students and further to their colleagues and former classmates willing to participate in the survey. So, the sample can be called a convenience one (Long, 2005). 80 per cent of informants received additional qualification "Translator in the Sphere of Professional Communication".

The respondents used a $0-3$ scale ( 3 being "extremely important") to assess the offered rubrics, answered the question whether a rubric had been included in the curriculum, and if the answer was "no" indicated the source the rubric(s) had been attained from. The results in terms of rubric importance were similar to findings in Case (Case 2013) because the highest average importance ' 3 ' was assigned to written and oral communication. The following table shows that Russian Law School graduates rate skills higher than knowledge sharing their American colleagues' point of view. 
Table 1

Average importance of knowledge and skills

\begin{tabular}{|c|l|l|}
\hline $\begin{array}{c}\text { Average } \\
\text { importance }\end{array}$ & \multicolumn{1}{|c|}{ Knowledge Domains } & \multicolumn{1}{c|}{ Skills } \\
\hline 3 & & Written Communication (Business Correspondence) \\
\hline 3 & & Oral Communication \\
\hline 2.89 & Civil Law & Client Interviewing \\
\hline 2.78 & & Drafting Contracts \\
\hline 2.56 & Arbitrazh & \\
\hline 2.33 & Family Law & \\
\hline 2.22 & Civil Procedure & Negotiations \\
\hline 2.11 & & Drafting Complaints \\
\hline 2 & & Communication with the Other Party \\
\hline 1.89 & Financial Law & \\
\hline 1.78 & & Communication with the Court (Judge) \\
\hline 1.67 & Administrative Law & \\
\hline 1.667 & Theory of State and Law & \\
\hline 1 & Criminal Law & \\
\hline 0.67 & Criminal Procedure & \\
\hline 0.56 & & Examination, cross-examination \\
\hline
\end{tabular}

It should be mentioned that such low scores of rubrics connected with criminal law are conditioned by the fact that the respondents have not passed a Bar exam yet and are not involved in practicing criminal law.

Indicated sources of obtaining knowledge and skills should be taken into account by curricula designers because all rubrics from the Knowledge Domains were named as studied within the curriculum but in the skills category only two rubrics, 'Examination, cross-examination' and 'Drafting Complaints', were mentioned as obtained in class. Other sources of attaining skills are the program of additional qualification "Translator in the Sphere of Professional Communication", law clinic, and/or internships.

So, the survey showed that FL teachers do contribute to law schools learning outcomes through fostering communicative competence in law students. However, what else can be done in a LE classroom to increase graduates' competitiveness and enhance their professionalism? 


\section{A Legal English Course Syllabus}

One of the ways to increase a professional communicative competence is using CLIL courses, however, accredited institutions of higher education are supposed to work out their curricula within approved standards, in Russia these are FSESes (see above) and a degree of freedom in designing a specific discipline syllabus is not high. This is one of the reasons of low level of implementing CLIL courses into university curricula, although interest to CLIL approach has grown significantly since the first detailed CLIL analysis was made and perspectives were outlined by David March (March 2002). Other reasons of low CLIL implementation in Russia are as follows: deficiency of subject teachers knowing a FL at a $\mathrm{C} 1$ or $\mathrm{C} 2$ level and ready to go through teacher training necessary for exercising this task, a great variety of students' level of FL knowledge, a complex subject matter (especially in a law school), etc.

However, literature analysis shows that there is a continuous work carried out by language and law teachers in designing CLIL courses for law students. Some of them are a European Law course taught in English with additional focus on acquiring technical vocabulary (Pluzhnikova, 2015), an optional course "Client Consultation in English" (Vyushkina, 2017), International law (Pestova, 2018). When university authorities support joint work of FL and law teachers and are open to innovations, teachers' and students' creative professional development achieves high levels (Atabekova, Gorbatenko, 2015).

Although implementing CLIL courses in highly standardized university curricula is a challenging and remote goal, incorporating elements of such courses in a foreign language course syllabus is an attainable task: choosing topics and including assignments aimed at formation and development of skills significant at a future working place can be a solution.

In terms of a skill-oriented syllabus several educational aims can be achieved. Firstly, understanding of practical orientation of assignments promotes a students' motivation increase and, therefore, improves the quality of learning. Secondly, such skills as analysis of information (in a FL lesson this is a text), cross-cultural and interpersonal communication (studying a foreign culture, in a broad sense, work in pairs and small groups), team work, etc. are extremely significant for life-long learning and equip future specialists with tools for professional development (Udina, 2015). These skills are often called transferrable and their framing has become an integral part of a good FL and/or ESP (English for Specific Purposes) course. However, the aim of this article is to elicit syllabus elements and assignments aimed at framing and mastering lawyering skills. 


\section{Elena Vyushkina}

Any communication is built around a topic which communicants are interested in. So, nowadays, FL courses are based on various topics presented through texts and in a LE course texts are devoted to legal topics ranging from government structure to overviews of particular branches of law in the English-speaking countries. It is analytical skills that can be formed and mastered through such assignments as comparing the main features of Russian law (domestic law) with the exemplified one. An experienced LE teacher usually has enough knowledge to asses even a legal element of answers but if he/she cannot do that there are always classmates who are ready to challenge subject matter omissions and/or mistakes and present their points of view, developing speaking skills at the same time.

To foster public speaking skills students are given assignments to prepare presentations on debatable questions of a studied topic and make them in class. This assignment can also be used to train team work if a task is given to a pair/small group. In fact, there are not many opportunities to train the public speaking skills during other classes and doing that in English will definitely improve this significant for a lawyer skill in a mother tongue, too.

Developing writing skills can be carried out by offering a range of assignments. Firstly, business correspondence has been an integral part of a LE course for a long time. Students are acquainted with a typical layout of a letter, learn the difference between formal and informal register, and acquire basics of records management. Globalization of business and legal interactions makes the rules of correspondence almost universal so knowledge of the subject in English provides students with general understanding of it in Russian as well. Secondly, students are offered to write summaries of real life cases and situations given them as reading material and this is the first step in writing briefs.

Work in pairs and/or small groups has always been typical for a FL course. In a LE context this work can be organized as simulations of lawyerclient interviews, negotiations of different problems (resolving a dispute, signing a contract, reaching a settlement, etc.), mediation (family or business matters). Such assignments develop and improve professional communicative skills together with problem-solving experience. Skills of active listening are introduced alongside with training questioning. Students are taught to ask different types of questions to clarify information or to get more facts and details. Clichés and rules of conducting an interview enhance students' awareness of professional ethics standards.

Thus a LE course enhanced with such CLIL elements as presenting and discussing topics connected with a native legal system in English, conducting lawyers' activities (interviews with clients, negotiations, mediation sessions) 
in English, putting down in writing the results of discussions and other oral communication (summaries, follow-up letters, contracts, etc.) will contribute to developing lawyering skills and law school learning outcomes as a whole.

\section{Conclusion}

Law schools aim at achieving goals and fulfilling requirements set up by authorized bodies. Learning outcomes can be put in various wording but their essence is the same in different countries - to educate graduates and prepare them for real life professional activities. With deep respect to substantive and procedurals rules of law it is necessary to underline the importance of professional communicative competence for lawyers' success in any legal career path. Framing and developing written and oral communication skills in a legal contest is an achievable goal for LE course designers and teachers.

LE textbooks have been improving constantly and, moreover, internet resources supply teachers with materials for organizing great variety of activities: moot courts, debates, negotiation and mediation simulations, lawyer-client interviews, etc., that is for mastering different aspects of oral communication. Written communication can be trained through such assignments as summaries, essays, business letters, elements of contracts drafting. The latter can habituate law-students to make bi-lingual contracts.

Engaging law teachers into creating elements of CLIL courses and promoting CLIL at the level of universities administration will enhance the quality of legal education and improve law schools learning outcomes.

\section{R E F E R E N C E S}

Atabekova A., Gorbatenko R. 2015. 'Foreign Language as a Tool for Creative Professional Development.' J Science Prospects. 11 (74): 198-200.

Bratman B. 2015. 'The 25 Most Important Lawyering Skills?' Retrieved from https://bestpracticeslegaled.albanylawblogs.org/2015/10/08/the-25-mostimportant-lawyering-skills-2/

Case S. 2013. 'Summary of the National Conference of Bar Examiners Job Analysis Survey Results' Retrieved from http://www.ncbex.org/pdfviewer/?file $=\% 2 \mathrm{~F}$ dmsdocument\%2F55

Christensen L. 2012. 'The Power of Skills: An Empirical Study of Lawyering Skills Grades as the Strongest Predictor of Law School Success (Or in Other Words, It's Time for Legal Education to Get Serious About Integrating Skills Training Throughout the Law School Curriculum If We Care About How Our Students Learn).' St. John's Law Review: Vol. 83: Iss. 3, Article 2. Retrieved from http://scholarship.law.stjohns.edu/lawreview/vol83/iss3/2 


\section{Elena Vyushkina}

Kruse K., McAdoo B., Press S. 2015. 'Client Problem-Solving: Where ADR and Lawyering Skills Meet.' Faculty Scholarship. Paper 268. Retrieved from http://open.mitchellhamline.edu/facsch/268

Levinson A. 2010. 'Lawyering Skills Principles and Methods Offer Insight as to Best Practices for Arbitration.' Bailor Law Review. Retrieved from https:// www.baylor.edu/content/services/document.php/116845.pdf

Long, M. 2005. Second Language Needs Analysis. Cambridge Applied Linguistics. Cambridge: Cambridge University Press.

MacCrate, R. 1996. 'Introduction: Teaching Lawyering Skills.' 75 Neb. L. Rev. Retrieved from https://digitalcommons.unl.edu/nlr/vol75/iss4/2

Marsh D. 2002. CLIL/EMILE: The European Dimension; Actions, Trends and Foresight Potential. Europäische Kommission Generaldirektion Bildung und Kultur, University of Jyväskyla. Retrieved from https://jyx.jyu.fi/dspace/bit stream/handle/123456789/47616/david_marsh-report.pdf?sequence=1

Martin, C. L. 2019. Testing Task Force's First Year Report. Retrieved from https://www.testingtaskforce.org/about/reports/

Pestova, E.V., Sorokina, A.G. 2018. 'Formation of Professional Competencies for Future Police Officers in the Universities of the Ministry of Internal Affairs of Russia by means of CLIL-Technologies.' (in Russian) Psychopedagogics in Law Enforcement, 2 (73): 57-61. DOI: 10.24411/1999-6241-2018-12009

Pluzhnikova J. 2015. 'Experience of applying the Content and Language Integrated Learning (CLIL) approach: course "European law (in English)".' J Bulletin of Law Faculty of Kolomna branch of Moscow Polytechnic University, 10: 159-171 (in Russian).

Portal of Federal State Educational Standards for Higher Education (in Russian) http://fgosvo.ru/fgosvo/151/150/24

Saratov State Law Academy. Major 40.03.01 Jurisprudence (in Russian) http://xn-80af5bzc.xn--p1ai/component/k2/item/1549-40-03-01

Thompson, S. E. 2009. 'Developing a Comprehensive Approach to Teaching Lawyering Skills: A Response to the MacCrate Report Fifteen Years Later.' Faculty Publications and Presentations. Paper 49. Retrieved from http:// digitalcommons.liberty.edu/lusol_fac_pubs/49

Udina N. 2015. 'Integrating Transferable Skills into LSP Curriculum. In: LSP Teaching and Specialized Translation Skills Training in Higher Education Institutions (LSP \& STST).' in Annual International Conference Proceedings. RF Ministry of Education and Science, Peoples' Friendship University of Russia, 237-238.

Vyushkina E. 2017. 'CLIL Approach to Legal English Courses: Analysis of Practice and Experience.' J Sustainable Multilingualism, 10: 136-148. DOI: https:// doi.org/10.1515/sm-2017-0007

Zimnaya I. 2013. 'Competence and competency in the context of competency-based approach in education.' J Bulletin of National Association of Applied Linguistics, 4: 16-31 (in Russian). 